\title{
EVALUASI SISTEM GENERAL LEDGER DENGAN BERBASIS APLIKASI ABI PRO
}

\author{
Noerlina'; Cahyadi W Stefanus ${ }^{2}$ \\ 1, 2 Jurusan Komputerisasi Akuntansi, Fakultas Ilmu Komputer, Universitas Bina Nusantara, \\ Jl. K.H. Syahdan No. 9, Kemanggisan/Palmerah, Jakarta Barat \\ 1nurlina@binus.ac.id
}

\begin{abstract}
The running evaluation system has purpose to make sure whether the control in general ledger information system was sufficient enough and also can support an effective and efficient performance. The evaluations are using interview, questioner, and observation method. The result was it can be known the positive and negative on every control and running application. The negative thing on application will be put on risk analysis table and also with recommendation on the negative things. The conclusion of the research was measure of the running information system, how far it was running with the control, and the important of the company awareness to make evaluation on the information system control.
\end{abstract}

Keywords: evaluation, information system, application, general ledger

\begin{abstract}
ABSTRAK
Evaluasi sistem yang dilakukan bertujuan untuk memastikan apakah pengendalian yang terdapat pada sistem informasi general ledger cukup memadai serta dapat mendukung terciptanya kinerja yang efektif dan efisien. Evaluasi yang dilakukan menggunakan metode wawancara, kuesioner, serta observasi. Hasil yang dicapai adalah diketahuinya hal positif dan negatif pada tiap pengendalian yang ada dan yang berjalan pada aplikasi. Hal negatif pada aplikasi yang ada akan dimasukkan dalam tabel analisis risiko dan disertai dengan rekomendasi terhadap hal negatif tersebut. Simpulan yang didapat adalah ukuran sejauh mana sistem informasi telah berjalan sesuai dengan pengendalian yang ada dan pentingnya kesadaran perusahaan untuk melakukan evaluasi terhadap pengendalian sistem informasi.
\end{abstract}

Kata kunci: evaluasi, sistem informasi, aplikasi, general ledger

\section{PENDAHULUAN}

Dalam melakukan fungsinya agar penggunaan sistem informasi dapat optimal maka diperlukan pengendalian yang memadai. Oleh karena itu, diperlukan sebuah evaluasi terhadap sistem informasi tersebut untuk menentukan apakah sistem tersebut sudah berjalan dengan efektif dan efisien. Salah satu sistem informasi perusahaan yang digunakan adalah Sistem Informasi General Ledger yang berfungsi untuk mengumpulkan semua data akuntansi dari subsistem perusahaan dan mengeluarkannya dalam bentuk informasi akuntansi. Evaluasi akan digunakan untuk mengukur besarnya risiko yang mungkin timbul dari penggunaan sistem informasi tersebut dan melihat apakah sistem informasi tersebut sudah cukup efektif dan efisien dalam mendukung kegiatan operasional sebuah perusahaan.

Pelaksanaan evaluasi sistem informasi yang dilakukan melingkupi hal berikut. Pertama, Sistem General Ledger berbasis aplikasi ABI Pro. Kedua, pengendalian perspektif manajemen untuk aplikasi ABI Pro yang meliputi kontrol manajemen operasional (operation management control) dan kontrol manajemen keamanan (security management control). Ketiga, pengendalian aplikasi untuk aplikasi ABI Pro yang meliputi kontrol input (input control), kontrol output (output control), dan kontrol batasan (Boundary control). Keempat, melakukan pengukuran risiko dari temuan audit.

Tujuan evaluasi sistem informasi yang dilakukan ialah dapat mengetahui kualitas kinerja sistem informasi, dapat memperkirakan risiko yang timbul dari penggunaan sistem informasi, dan dapat 
meningkatkan kinerja sistem informasi untuk mendukung kegiatan operasional dan pengambilan keputusan.

Manfaat evaluasi sistem informasi ialah dapat diketahui kekurangan pada sistem informasi yang memungkinkan untuk dilakukannya perbaikan pada sistem informasi tersebut, dapat menerapkan pengendalian untuk menghindari risiko atas sistem informasinya, dan mampu memaksimalkan kinerja Sistem Informasi untuk mencapai efektivitas dan efisiensi dalam kegiatan operasional.

Metode evaluasi yang akan digunakan dalam mengevaluasi adalah sebagai berikut. Pertama, studi kepustakaan. Metode ini dilakukan dengan mempelajari kasus mengenai evaluasi sistem informasi yang terdapat dalam kepustakaan. Studi kasus yang dilakukan bertujuan untuk membantu dan mendukung kegiatan studi lapangan dan evaluasi yang dilakukan. Kedua, studi lapangan. Studi lapangan yang digunakan sebagai berikut. Pertama, observasi. Metode ini dilakukan dengan mengamati sistem informasi yang terkait dengan aplikasi ABI Pro. Pengamatan juga akan dilakukan pada kegiatan operasional sehingga memungkinkan untuk memahami secara jelas aktivitas dalam perusahaan tersebut. Kedua, wawancara. Metode ini dilakukan dengan melakukan wawancara dengan beberapa orang yang terkait dengan sistem informasi yang ada (dengan fokus, aplikasi ABI Pro) sehingga dapat diketahui penggunaan dan cara kerja sistem tersebut. Ketiga, Questioner. Metode ini dilakukan dengan memberikan questioner kepada para pegawai yang berhubungan langsung dengan sistem sehingga dapat mengukur kinerja dari sistem aplikasi yang digunakan. Keempat, Testing. Metode ini dilakukan dengan melakukan uji coba sistem aplikasi yang digunakan, yaitu aplikasi ABI Pro. Keempat, studi dokumentasi. Metode ini dilakukan dengan mempelajari laporan yang telah dibuat oleh perusahan.

\section{PEMBAHASAN}

\section{Tinjauan Pustaka}

Weber (1999:10) menyebutkan bahwa audit sistem informasi adalah proses mengumpulkan dan mengevaluasi bukti untuk memastikan apakah sebuah sistem komputer telah menjaga aset, mempertahankan integritas data, memungkinkan tujuan organisasi tercapai secara efektif, dan menggunakan sumber daya secara efisien.
Definisi dari laporan COSO (COSO dalam Moscove et. al., 2001:211) mengutarakan bahwa pengendalian intern adalah sebuah proses yang dibuat oleh dewan direksi, manajemen, dan personel lain dalam suatu perusahaan, didesain untuk menyediakan jaminan yang wajar mengenai pencapaian tujuan dalam kategori berikut: efektivitas dan efisiensi operasi, keandalan laporan finansial, dan ketaatan dengan undang-undang dan peraturan yang berlaku.

Menurut Moscove, Simkin, dan Bagranoff (2001:210-212), sebuah pengendalian intern terdiri dari berbagai metode dan pengukuran yang didesain dan diimplementasikan dalam sebuah sistem organisasi untuk mencapai empat tujuan, yaitu menjaga aset, memeriksa keakuratan dan keandalan data akuntansi, mendorong efisiensi operasional, dan mendorong ketaatan pada kebijakan yang dibuat manajemen.

Sistem pengendalian intern pada sistem berbasis komputer dapat diklasifikasikan menjadi dua kategori: Pengendalian perspektif manajemen atau general control. General Control adalah sistem pengendalian intern komputer yang berlaku umum, meliputi seluruh kegiatan komputerisasi sebuah organisasi secara menyeluruh; Pengendalian aplikasi atau application control. Application Control adalah sistem pengendalian intern pada sistem informasi berbasis teknologi informasi yang berkaitan dengan pekerjaan atau kegiatan atau aplikasi tertentu.

\section{Perencanaan Evaluasi Sistem Informasi}

Setelah mengidentifikasikan sistem yang berjalan maka untuk melakukan evaluasi diperlukan sebuah perencanaan yang baik sehingga pelaksanaan evaluasi dapat dilakukan secara maksimal. Perencanaan evaluasi terdiri dari hal berikut. Pertama, menentukan ruang lingkup evaluasi. Ruang lingkup evaluasi terdiri dari sistem general ledger/ buku besar berbasis aplikasi ABI Pro, pengendalian perspektif manajemen: operation management control dan security management control, pengendalian aplikasi: input control, output control, dan boundary control. Kedua, memahami pengendalian internal. Dalam memahami pengendalian internal dan mengidentifikasi pengendalian internal maka dilakukan observasi dalam perusahaan dan melakukan kajian pada struktur organisasi perusahaan dan sistem perusahaan yang berjalan.

Ketiga, melakukan test audit dengan instrumen audit. Instrumen audit yang digunakan untuk tes audit ialah dengan menyebarkan kuisioner, melakukan wawancara, melakukan observasi, 
testing, dan studi dokumentasi kemudian dilakukan pengukuran risiko dari temuan audit. Keempat, membuat simpulan evaluasi dan memberikan rekomendasi atas evaluasi yang dilakukan. Setelah melakukan evaluasi pada sistem general ledger maka disimpulkan hasil evaluasi yang telah dilakukan dan diberikan rekomendasi yang sesuai jika terdapat kelemahan dalam sistem general ledger tersebut.

\section{Program Evaluasi}

Setelah menetapkan rencana evaluasi, dilakukan survey ke perusahaan. Melalui survey yang dilakukan oleh peneliti, audit sistem informasi aplikasi general ledger dimulai ketika bagian accounting menerima dokumen sumber mengenai transaksi dari departemen lain yang akan dimasukkan ke dalam sistem sampai bagian accounting mencetak laporan, baik laporan keuangan maupun laporan manajerial. Metode audit yang digunakan dalam pelaksanaan audit adalah metode audit around the computer. Peneliti memfokuskan pelaksanaan audit pada metode audit around the computer karena sistem yang dievaluasi tidak terlalu besar dan kompleks, menggunakan paket software yang umum sehingga fokus evaluasi lebih ditekankan kepada realibilitas pengendalian user dibandingkan dengan pengendalian komputer. Pelaksanaan audit difokuskan pada pengendalian manajemen dan pengendalian aplikasi. Pengendalian manajemen terdiri dari pengendalian manajemen operasional (operating management control) dan pengendalian manajemen keamanan (security management control) sedangkan pengendalian aplikasi terdiri dari pengendalian batasan (boudary control), pengendalian input (input control), dan pengendalian output (output control).

Untuk pengumpulan bahan bukti evaluasi, digunakan beberapa instrumen audit, yaitu wawancara, kuesioner, dan observasi. Wawancara dilakukan dengan kepala bagian accounting, kuesioner disebarkan kepada staff accounting, dan peneliti melakukan observasi terhadap pelaksanaan pengendalian oleh pihak manajemen dan penggunaan aplikasi general ledger oleh user. Selain itu, peneliti juga melakukan studi dokumentasi terhadap dokumen sumber dan testing terhadap aplikasi ABI Pro untuk mendukung pengumpulan bukti evaluasi dari instrumen yang telah disebutkan sebelumnya.

\section{Temuan}

Sebagai referensi untuk temuan yang ada, peneliti mempunyai beberapa istilah untuk sumber bukti, yaitu K untuk Kuisioner, W untuk Wawancara, O untuk Observasi, SD untuk Studi Dokumentasi, dan L untuk Lampiran.

\section{Temuan positif evaluasi: \\ Operation Management Control}

1. Bagian entry data dan bagian pengelola data dipisah. Pemisahan ini mempunyai tujuan untuk menghindari terjadinya manipulasi data.(K1,W1,O1)

2. Pemeriksaan data dilakukan setiap hari oleh bagian pengelola data. Pemeriksaan data dilakukan untuk menghindari dan memperbaiki terjadinya kesalahan sewaktu meng-entry data sebelum data diproses ke dalam buku besar.(K3,W3,O3)

3. Terdapat prosedur pembatasan pemakaian dan hak dalam aplikasi. Prosedur ini memungkinkan adanya pembatasan pemakaian dan hak sesuai dengan tanggung jawab yang telah ditentukan oleh pihak manajemen sehingga data dan informasi yang penting dapat dilindungi.(K4,W4,O4)

4. Terdapat pengendalian personel yang dilakukan oleh bagian HRD. Pengendalian personel ini dengan tujuan untuk mengatur para personel yang bekerja sehingga sesuai dengan peraturan yang telah dibuat oleh manajemen dan juga untuk mendapatkan kinerja yang maksimal sesuai dengan kemampuan para pekerja.(K5-8,W5-7,O5)

5. Ruangan yang terdiri dari jendela kaca. Jendela kaca yang dapat melihat langsung ke dalam ruangan dengan tujuan untuk memudahkan pengawasan pada server dan komputer setiap saat oleh para kepala bagian maupun oleh para direksi.(K9,W8,O6)

6. Terdapat prosedur pemeliharaan rutin dan penanganan kerusakan untuk kerusakan yang terjadi pada hardware dan software. Prosedur ini mempunyai tujuan untuk penanganan yang akan dilakukan pada hardware dan software yang mengalami kerusakan sehingga dapat kerusakan dapat ditanggulangi secepatnya.(K13,W10,O9)

7. Semua data tersimpan dalam server. Data yang tersimpan dalam server dapat mencegah terjadinya pengandaan data oleh orang-orang yang tidak berhak atas data tersebut dan memudahkan untuk memonitor space yang terisi dan kosong pada sebuah komputer.(O10) 
8. Terdapat monitoring jumlah space kosong pada hard disk. Monitoring ini mempunyai tujuan untuk mengetahui jumlah space yang masih kosong untuk menyimpan data perusahaan sehingga hard disk tidak overload yang dapat menyebabkan operating system dan aplikasi tidak berjalan dengan lancar atau hang.(K15,O11)

9. Adanya software yang mengatur dan memproteksi jaringan. Hal itu dapat mencegah akses dari pihak yang tidak berwenang dan memproteksi komputer dari gangguan yang berasal dari komputer lain. (K18, W12)

10. Adanya orang yang bertanggung jawab atas server. Orang yang bertanggung jawab atas server ini berfungsi memantau server dan kinerja server tersebut sehingga bila terjadi suatu ketidakberesan pada server dapat ditangani secara langsung.(K19, O13)

11. Terdapat pengendalian yang cukup baik pada lingkungan bekerja. Pengendalian ini berfungsi untuk memastikan para pekerja dapat cukup nyaman dan mendapatkan peralatan yang baik sehingga dapat memaksimalkan kinerja mereka.(K2024,014)

\section{Security Management Control}

1. Terdapat alat pemadam kebakaran atau fire extinguisher dibeberapa titik wilayah perusahaan. Alat pemadam kebakaran ini membantu untuk memadamkan api bila terjadi kebakaran dan jumlah dari fire extinguisher ini cukup banyak yang diletakkan dengan komputer yang ada.(K1,W1,O1)

2. Terdapat Air Conditioner (AC) disetiap ruangan. $A C$ ini digunakan untuk menjaga suhu ruangan agar tetap sejuk sehingga komputer yang sedang digunakan tidak overheat.(K5,W2,O4)

3. Ruangan komputer user dan server terletak di lantai 2. Hal itu mengurangi risiko terhadap ancaman banjir karena semua material aset sistem informasi ditaruh ditempat yang tinggi. (K6, O5)

4. Terdapat stabilizer untuk setiap komputer. Stabilizer digunakan untuk melindungi komputer dari tegangan listrik yang terlalu rendah atau terlalu tinggi.(K7,W3,O6)

5. Terdapat MCB yang digunakan jika tegangan listrik terlalu tinggi. MCB ini digunakan untuk memadamkan tegangan listrik bila tegangan listrik terlalu tinggi sehingga alat elektronik yang digunakan dapat dilindungi.(K9,W4,O8)

6. Ruangan dibersihkan setiap hari secara rutin. Prosedur ini mempunyai tujuan agar debu yang menempel di lantai dapat disingkirkan sehingga tidak terhisap ke dalam kipas $C P U$ yang sedang digunakan di dalam kantor.(K12,W6,O11)

7. Terdapat prosedur backup data aplikasi. Prosedur ini dilakukan agar data perusahaan dapat dilindungi dari penghapusan yang tidak sengaja oleh orang yang tidak bertanggung jawab, kerusakan software yang mengakibatkan data hilang, serangan virus atau spyware yang mengancam keberadaan data.(K15,W7,O13)

\section{Boundary Control}

1. Terdapat penggunaan user name dan password pada saat $\log$ in. Penggunaan user name dan password digunakan agar user yang dapat diidentifikasi dengan baik oleh aplikasi sehingga akses ke dalam data dan informasi dapat dilindungi.(K1,W1,O1)

2. Terdapat penggunaan karakter yang disamarkan, yaitu * ketika password digunakan. Penggunaan karakter yang disamarkan ini digunakan agar password tidak dapat terlihat oleh orang lain ketika sedang $\log$ in dan menjadi rahasia bagi si pemilik password tersebut.(K2,O2)

3. Terdapat hak akses yang berbeda untuk masing-masing pengguna aplikasi ABI Pro. Hak akses yang berbeda untuk masingmasing pengguna ini mempunyai tujuan agar memberikan batasan akses sesuai dengan jabatan di dalam perusahaan sehingga informasi penting, seperti laporan hanya dapat dibuka oleh orang yang memiliki akses tersebut. (K5,W2,O5)

\section{Input Control}

1. Terdapat penggunaan dokumen sumber, seperti faktur penjualan. Penggunaan dokumen sumber ini digunakan untuk menelusuri komponen data yang dimasukkan ke dalam aplikasi ABI Pro jika terjadi kesalahan oleh orang yang mengentry data, misalnya salah memasukkan jumlah uang. (SD,L4.16)

2. Desain dokumen sumber yang cukup baik, seperti penggunaan no faktur, kode pelanggan, kode barang, tanggal faktur. 
Desain dokumen sumber yang baik akan memudahkan entry data ke dalam aplikasi ABI Pro. (SD, L4.16)

3. Data aplikasi yang telah disimpan dapat langsung dilihat kembali. Data yang telah disimpan dapat langsung dilihat kembali sehingga dapat dilakukan perbaikan jika terjadi kesalahan dalam menginput data (K3, O4)

4. Tampilan aplikasi sudah terbagi dan dikelompokkan berdasarkan kategori komponen form. Tampilan yang sudah terbagi dan dikelompokkan berdasarkan kategori komponen form membantu user agar mudah mencari form yang ingin digunakan (K4, W2, O5) .

5. Tampilan aplikasi yang ada sudah cukup baik, terlihat dari ukuran huruf yang cukup memadai dan terbaca (K5, O6), terdapat keterangan mengenai cara mengisi komponen form (K6, W3, O7), posisi kursor yang tidak melakukan auto skip (K7, W4, O8), serta penggunaan warna yang sesuai dan cukup nyaman di mata (K8, W5). Tampilan aplikasi yang baik akan mengurangi kesalahan input serta menambah kenyamanan dalam peng-inputan untuk mencapai sistem input yang efektif dan efisien.

6. Program aplikasi tidak akan meneruskan fungsinya sebelum user membetulkan kesalahan yang diperbuat atau memilih keluar (K10, W6, O10), hal itu dapat mengurangi tingkat error dalam peng-inputan karena peng-input-an tidak akan berjalan tanpa nilai dan format yang benar.

7. Terdapat pencocokkan antara jumlah transaksi dengan jumlah input yang telah dilakukan. Hal itu untuk memastikan bahwa semua transaksi yang ada telah di-input dengan benar. (K13, W9, O13)

8. Setiap kali user ingin melakukan manipulasi data, aplikasi akan mengkonfirmasi terlebih dahulu. Hal itu dapat mencegah manipulasi data secara tidak disengaja oleh user dan sebagai konfirmasi sebelum user akan melanjutkan kegiatan manipulasi data. (O11)

9. Ada pemberitahuan kecil di ujung kanan atas aplikasi, jika user salah memasukkan kode sebelum program dilanjutkan. Pemberitahuan kecil ini memberitahukan agar user memasukkan data sesuai dengan prosedur aplikasi sehingga data yang terisi sesuai dengan jenisnya data yang dibutuhkan.(K10,W6,O10)

10. Adanya verifikasi ketika data akan dihapus. Verifikasi itu membantu user untuk mempertimbangkan data yang akan dihapus sehingga meminimalisasi kesalahan penghapusan yang tidak disengaja.(K11,W7,O11)

11. Kode yang terkait dengan buku besar dirancang dengan sederhana. Kode membantu user agar dapat cepat mengingat kode tersebut sehingga mempercepat entry data yang dilakukan. Selain itu, pada aplikasi terdapat menu drop down yang dapat memberikan keterangan pada user mengenai kode dan nama asli (perkiraan/pelanggan/ supplier) yang diwakilkan kode (K12,W8,O12,SD L4.21)

12. Terdapat pemeriksaan terhadap peng-inputan jurnal dengan dokumen sumber dari segi total jumlah uang dan kesesuaian dengan dokumen sumber oleh kepala bagian akuntansi. Hal itu dilakukan setiap sore hari (K13,W9,O13)

13. Terdapat pemeriksaan field oleh aplikasi termasuk field yang memiliki kesalahan input. Akan muncul sebuah peringatan disebelah ujung kanan atas aplikasi atau sebuah dialog box. Pemeriksaan field oleh aplikasi ini dilakukan agar data yang dimasukkan sesuai dengan prosedur aplikasi ABI Pro. (K14, O15)

14. Menu yang ada tersusun cukup baik. Interface aplikasi yang rapi membuat aplikasi menjadi user friedly sehingga user dapat efektif dan efisien dalam menggunakan aplikasi tersebut.(K17,O16)

15. Menu dikelompokkan berdasarkan fungsi dan tidak ada kesulitan bagi user untuk memahami menu tersebut. User dapat segera menemukan menu yang ingin dicari dan digunakan.(K18,O16)

16. Aplikasi mempunyai audit trail untuk subsistem input dalam bentuk nama user, waktu, kegiatan peng-input-an, dan jumlah yang di-input.(K19, O17)

\section{Output Control}

1. Perusahaan mempunyai preprinted stationery dalam kegiatan sehari-hari. Hal itu dapat membuat output lebih jelas dibaca dan menghemat pemakaian tinta. (K1,W1)

2. Preprinted stationery disimpan di tempat yang aman $(\mathrm{K} 3, \mathrm{O} 2)$. Walaupun karyawan 
diberikan kebebasan untuk meminta dan mengambil sendiri preprinted stationery yang dibutuhkan tetapi diperlukan otorisasi untuk mengambil preprinted stationery tersebut sehingga penggunaan preprinted stationery dapat dikontrol (K4,W2,O2).

3. Output yang dihasilkan akan diberikan nomor urut secara otomatis oleh aplikasi ketika dicetak. Hal itu dapat mencegah duplikasi output, memudahkan pengontrolan atas pencetakan output, dan memudahkan pencarian output ketika dibutuhkan. (K5,W3,O3,SD L4.23)

4. Terdapat pembatasan untuk menghasilkan laporan keuangan. Pembatasan ini bertujuan agar laporan dapat dihasilkan oleh orangorang yang mempunyai wewenang dan hak dalam perusahaan sehingga kerahasiaan informasi perusahaan dapat dijaga. (K6,O4)

5. Ketika laporan tidak selesai tercetak, laporan dapat dicetak dari halaman sebelumnya, hal itu didukung oleh aplikasi dan dapat mencegah pemborosan sumber daya akibat terjadinya kesalahan pencetakan. (O6)

6. Letak printer yang mudah untuk diawasi. Letak printer yang mudah diawasi memudahkan agar adanya pengawasan dokumen atau laporan yang tercetak dan juga mencegah printer tersebut digunakan untuk kepentingan pribadi karyawan. (K13,O7)

7. Laporan dicetak jika dibutuhkan saja. Hal itu dapat membantu perusahaan dalam menghemat sumber daya yang ada. (K14)

8. Sebelum dan sesudah dicetak, dilakukan pengecekan terhadap output dengan fasilitas print preview dalam aplikasi. Hal itu dapat mengurangi kesalahan dan pemborosan sumber daya yang tidak perlu dalam pencetakan laporan (K19-20, O15).

9. Terdapat sistem yang mengingatkan jika terjadi ketidaksiapan alat pencetak output. Hal itu akan mencegah terjadinya kegagalan pencetakan output di tengah jalan. Namun, sistem ini hanya terdapat pada printer tinta. (K18,W6, O5)

10. Tempat penyimpanan laporan diawasi langsung oleh bagian Accounting. Pengawasan langsung pada penyimpanan laporan ini bertujuan agar laporan hanya dapat dilihat atau diperiksa oleh orang-orang yang berwenang didalam perusahaan.(K25,O11)

11. Folder dicantumkan nama dokumen dan tanggal dokumen sesuai periode laporan.
Pencantuman nama dokumen dan tanggal dokumen memudahkan untuk mencari kembali folder laporan jika sewaktu-waktu ingin digunakan kembali. (K21, W5)

12. Aplikasi mempunyai audit trail untuk subsistem output dalam bentuk jumlah laporan.(O14)

\section{Temuan negatif : \\ Operation Management Control}

1. Bagian kasir dan entry data tidak dipisah.(K2,W2,O2)

2. Tidak adanya prosedur pengisian agenda kunjungan dan penggunaan tanda pengenal tamu. (K10-11,O7)

3. Ruangan server dapat dimasuki oleh bagian lain, selain bagian akuntasi dan bagian keuangan.(K12,W9,O8)

4. Tidak adanya monitoring terhadap aktivitas pemakaian dan pola perjalanan data.(K16,O12)

5. Help desk hanya berjalan diluar aplikasi.(K26,O15)

\section{Security Management Control}

6. Tidak terdapat smoke detector dan alarm kebakaran.(K2, O2)

7. Tidak adanya UPS yang digunakan pada komputer atau server.(K4,O3)

8. Lantai terbuat dari bahan kayu yang mudah terbakar.(O17)

9. Komputer tidak ditutup oleh kain pengaman yang tahan air. $(\mathrm{K} 8, \mathrm{O} 7)$

10. Tidak ada alat untuk mengamankan peripheral komputer, seperti laci, lemari komputer yang dapat dikunci dari luar.(K10,O9)

11. Beberapa tempat sampah dekat komputer tidak kedap air.(K11,W5,O10)

12. Tidak ada prosedur pemulihan dari bencana alam.(K13,O12)

13. Program antivirus yang terpasang dibeberapa komputer tidak ter-update. (K17, O15)

14. Tidak ada prosedur menghadapi bencana.(K16,O14)

15. Data-data perusahaan tidak dienkripsi.(K18,O16)

\section{Boundary Control}

16. Tidak ada pembatasan password. (K3, O3)

17. Tidak adanya penggantian password yang dilakukan secara rutin bagi user.( $\mathrm{K} 4, \mathrm{O} 4)$ 
18. Tidak adanya kebiasaan pengguna untuk $\log$ out dari aplikasi yang sedang digunakan. (K6, W3, O6)

19. Aplikasi tidak meminta user name dan password jika aplikasi tersebut ditinggal terlalu lama tanpa di logout. $(\mathrm{K} 7, \mathrm{O} 7)$

\section{Input Control}

20. Aplikasi terkadang tidak memberitahukan kesalahan yang diperbuat secara jelas. (K16,O14)

\section{Output Control}

21. Pembuatan laporan tidak dibatasi dari segi duplikas, dan periode laporan. (K7)

22. Jumlah halaman laporan tidak tercetak (K8)

23. Untuk printer pita, tidak terdapat fasilitas yang memberitahukan jika terjadi kehabisan pita. (W6,O5)

24. Bila tidak sampai ke tujuan, laporan tidak disimpan di tempat yang aman. (K15, W4, O8)
25. Tidak ada konfirmasi bagi dokumen yang sudah diterima dan tidak ada pencatatan bagi dokumen yang belum diterima. (K16)

26. Penataan penyimpanan output yang kurang rapih dan teratur sehingga agak sulit mencari output lama dalam tempat penyimpanan output.(W7,O13)

27. Tempat penyimpanan dokumen tidak cukup kuat, tahan api, maupun gempa. (K26, W8, O12)

28. Output tidak pernah dibuang atau dihancurkan.(K32,W10,O13)

\section{Hasil Studi Dokumentasi dan Testing}

Code Control (Kode yang terkait dengan Aplikasi General Ledger)

\begin{tabular}{|c|c|c|c|c|c|}
\hline Faktor & $\begin{array}{c}\text { Kode } \\
\text { perkiraan }\end{array}$ & $\begin{array}{c}\text { Kode } \\
\text { voucher }\end{array}$ & $\begin{array}{l}\text { Kode } \\
\text { jurntal }\end{array}$ & $\begin{array}{c}\text { Kode } \\
\text { Supplier }\end{array}$ & $\begin{array}{c}\text { Kode } \\
\text { pelanggan }\end{array}$ \\
\hline $\begin{array}{c}\text { Panjang Kode yang } \\
\text { baik }\end{array}$ & $\bar{X}$ & & & $\mathrm{X}$ & $\mathrm{X}$ \\
\hline $\begin{array}{c}\text { Campuran alfabet dan } \\
\text { angka yang baik }\end{array}$ & & $\mathrm{X}$ & $\mathrm{X}$ & $\mathrm{X}$ & $\mathrm{X}$ \\
\hline $\begin{array}{c}\text { Pemilihan karakter } \\
\text { yang baik }\end{array}$ & $\mathrm{X}$ & & & $\mathrm{X}$ & $\mathrm{X}$ \\
\hline $\begin{array}{c}\text { Campuran huruf } \\
\text { besar dan huruf kecil } \\
\text { yang baik }\end{array}$ & $\mathrm{X}$ & $\mathrm{X}$ & $\mathrm{X}$ & $\mathrm{X}$ & $\mathrm{X}$ \\
\hline $\begin{array}{c}\text { Penerkaan karakter } \\
\text { yang baik }\end{array}$ & $\mathrm{X}$ & $\mathrm{X}$ & $\mathrm{X}$ & $\mathrm{X}$ & $\mathrm{X}$ \\
\hline Kualitas Kode & Baik & Cukup & Cukup & Baik & Baik \\
\hline
\end{tabular}




\section{Source Document Design (Input Control)}

\begin{tabular}{|c|c|c|c|c|c|c|}
\hline Pengendalian & $\begin{array}{c}\text { Form } \\
\text { dinas } \\
\text { luar kota }\end{array}$ & $\begin{array}{c}\text { Form } \\
\text { transaksi } \\
\text { pe njualan }\end{array}$ & $\begin{array}{c}\text { Form } \\
\text { permintaan } \\
\text { barang }\end{array}$ & $\begin{array}{c}\text { Rekap } \\
\text { stok } \\
\text { barang }\end{array}$ & $\begin{array}{c}\text { Faktur } \\
\text { Penjualan }\end{array}$ & $\begin{array}{c}\text { Rekap } \\
\text { uang } \\
\text { makan }\end{array}$ \\
\hline Preprinted & $\mathrm{X}$ & $\mathrm{X}$ & & & & \\
\hline $\begin{array}{l}\text { Judul, kop, dan } \\
\text { instruksi }\end{array}$ & $\mathrm{X}$ & $\mathrm{X}$ & $\mathrm{X}$ & $\mathrm{X}$ & $\mathrm{X}$ & $\mathrm{X}$ \\
\hline $\begin{array}{l}\text { Teknik } \\
\text { penekanan dan } \\
\text { perbedaan }\end{array}$ & $\mathrm{X}$ & & $\mathrm{X}$ & $\mathrm{X}$ & $\mathrm{X}$ & $\mathrm{X}$ \\
\hline Keteraturan field & $\mathrm{X}$ & $\mathrm{X}$ & $\mathrm{X}$ & $\mathrm{X}$ & $\mathrm{X}$ & $\mathrm{X}$ \\
\hline Caption & $\mathrm{X}$ & $\mathrm{X}$ & $\mathrm{X}$ & $\mathrm{X}$ & $\mathrm{X}$ & $\mathrm{X}$ \\
\hline \multicolumn{7}{|l|}{ Multiple answer } \\
\hline \multicolumn{7}{|l|}{ Tick marks } \\
\hline \multicolumn{7}{|l|}{ Instruksi format } \\
\hline $\begin{array}{l}\text { Spacing yang } \\
\text { tepat }\end{array}$ & $\mathrm{X}$ & $\mathrm{X}$ & $\mathrm{X}$ & $\mathrm{X}$ & $\mathrm{X}$ & $\mathrm{X}$ \\
\hline $\begin{array}{l}\text { Posisi field sesuai } \\
\text { dengan input }\end{array}$ & $\mathrm{X}$ & $\mathrm{X}$ & $\mathrm{X}$ & $\mathrm{X}$ & $\mathrm{X}$ & $\mathrm{X}$ \\
\hline Prenumber & & & $\mathrm{X}$ & & $\mathrm{X}$ & \\
\hline $\begin{array}{l}\text { Standar } \\
\text { perusahaan }\end{array}$ & $\mathrm{X}$ & $\mathrm{X}$ & $\mathrm{X}$ & $\mathrm{X}$ & $\mathrm{X}$ & $\mathrm{X}$ \\
\hline
\end{tabular}

\section{Report Design (Output Control)}

\begin{tabular}{|c|c|c|c|c|c|c|c|}
\hline Pengendalian & $\begin{array}{l}\text { Laporar } \\
\text { Voucher }\end{array}$ & $\begin{array}{c}\text { Laporan } \\
\text { Jurnal }\end{array}$ & $\begin{array}{c}\text { Laporan } \\
\text { Buku } \\
\text { Besar }\end{array}$ & $\begin{array}{l}\text { Laporan } \\
\text { Ke uangan }\end{array}$ & $\begin{array}{c}\text { Laporan } \\
\text { Hutang }\end{array}$ & $\begin{array}{l}\text { Laporan } \\
\text { Piutang }\end{array}$ & $\begin{array}{l}\text { Laporan } \\
\text { HPP }\end{array}$ \\
\hline $\begin{array}{l}\text { Nama } \\
\text { Laporan }\end{array}$ & $\mathrm{X}$ & $\bar{X}$ & $\mathrm{x}$ & $\mathrm{X}$ & $\bar{X}$ & $\bar{X}$ & $\mathrm{X}$ \\
\hline $\begin{array}{l}\text { Tanggal dan } \\
\text { waktu } \\
\text { produksi }\end{array}$ & $\mathrm{x}$ & $\mathrm{X}$ & $\mathrm{X}$ & $\mathrm{X}$ & $\mathrm{X}$ & $\mathrm{X}$ & $\mathrm{X}$ \\
\hline $\begin{array}{l}\text { Periode } \\
\text { laporan }\end{array}$ & $\mathrm{X}$ & $\mathrm{X}$ & $\mathrm{X}$ & $\mathrm{X}$ & $\mathrm{X}$ & $\mathrm{X}$ & $\mathrm{x}$ \\
\hline $\begin{array}{l}\text { Versi } \\
\text { program }\end{array}$ & & & & & & & \\
\hline $\begin{array}{l}\text { Contact } \\
\text { Person }\end{array}$ & $\mathrm{x}$ & $\mathrm{x}$ & $\mathrm{x}$ & & & & \\
\hline $\begin{array}{l}\text { Security } \\
\text { Classification }\end{array}$ & & & & & & & \\
\hline $\begin{array}{l}\text { Retention } \\
\text { date }\end{array}$ & & & & & & & \\
\hline Page heading & $\mathrm{X}$ & $\mathrm{x}$ & $\mathrm{X}$ & $\mathrm{X}$ & $\mathrm{X}$ & $\mathrm{X}$ & $\mathrm{X}$ \\
\hline $\begin{array}{l}\text { Number of } \\
\text { Pages }\end{array}$ & & & & & & & \\
\hline Page number & $\mathrm{X}$ & $\mathrm{X}$ & $\mathrm{X}$ & $\mathrm{X}$ & $\mathrm{X}$ & $\mathrm{X}$ & $\mathrm{X}$ \\
\hline $\begin{array}{l}\text { End-of-job } \\
\text { marker }\end{array}$ & $\mathrm{X}$ & $\mathrm{X}$ & $\mathrm{X}$ & $\mathrm{X}$ & $\mathrm{X}$ & $\mathrm{X}$ & $\mathrm{X}$ \\
\hline
\end{tabular}




\section{Temuan, Risiko, dan Rekomendasi}

\section{Pengendalian Manajemen}

Pengendalian Manajemen Operasional (Operation Management Control)

\begin{tabular}{|c|c|c|c|}
\hline $\mathrm{N}_{0}$ & Temuan & Rekome ndasi & PIC \\
\hline 1 & $\begin{array}{l}\text { Bagian kasir dan entry } \\
\text { data tidak dipisah }\end{array}$ & $\begin{array}{l}\text { Adanya perrisahan tugas antara bagian } \\
\text { kasir dan entry data }\end{array}$ & Direksi \\
\hline 2 & $\begin{array}{lr}\text { Tidak ada } & \text { prosedur } \\
\text { pengisian } & \text { agenda } \\
\text { kunjungan } & \text { dan } \\
\text { penggunaan } & \text { tanda } \\
\text { pengenal tamu. } & \end{array}$ & $\begin{array}{l}\text { Tamu yang masuk diwajibkan mengisi } \\
\text { buku tamu dan me makai kartu tanda } \\
\text { pengenal tamu. }\end{array}$ & Security \\
\hline 3 & $\begin{array}{l}\text { Ruangan server dapat } \\
\text { dimasuki oleh bagian } \\
\text { lain selain bagian } \\
\text { akuntansi } \\
\text { keuangan. }\end{array}$ & $\begin{array}{l}\text { Dibuat sebuah kebijakan agar nuangan } \\
\text { server hanya boleh dimasuki oleh } \\
\text { karyawan akuntansi dan keuangan atau } \\
\text { memindahkan server pada sebuah } \\
\text { nuangan khusus dan terlindungi dengan } \\
\text { baik dari akses yang tidak sah }\end{array}$ & $\begin{array}{l}\text { Kepala } \\
\text { bagian } \\
\text { masing- } \\
\text { masing }\end{array}$ \\
\hline 4 & $\begin{array}{l}\text { Tidak ada pengawasan } \\
\text { terhadap aktivitas } \\
\text { pernakaian dan pola } \\
\text { perjalanan data }\end{array}$ & $\begin{array}{l}\text { Memory server diperbesar agar dapat } \\
\text { menampung beban yang lebih besar. }\end{array}$ & IT Support \\
\hline 5 & $\begin{array}{l}\text { Help desh hanya dapat } \\
\text { berjalan di luar aplikasi }\end{array}$ & $\begin{array}{l}\text { Menghubungi pihak pembuat ABI Pro } \\
\text { untuk mengaktifkan help desh, atau } \\
\text { perusahaan membuat help desh, intern } \\
\text { untuk karyawannya. }\end{array}$ & $\begin{array}{l}\text { IT Support } \\
\text { \& pihak } \\
\text { ABI Pro }\end{array}$ \\
\hline
\end{tabular}

Pengendalian Manajemen Keamanan (Security Management Control)

\begin{tabular}{|c|c|c|c|}
\hline No & Te muan & Rekomendasi & PIC \\
\hline 1 & $\begin{array}{l}\text { Tidak terdapat smoke detector dan } \\
\text { alarm kebakaran. }\end{array}$ & $\begin{array}{l}\text { Dipasang smoke detector pada } \\
\text { tuangan yang rawan kebakaran } \\
\text { dan alarm kebakaran yang dapat } \\
\text { didengar oleh semua karyawan. }\end{array}$ & $\begin{array}{l}\text { Bagian } \\
\text { Teknisi }\end{array}$ \\
\hline 2 & $\begin{array}{l}\text { Tidak terdapat UPS yang dapat } \\
\text { digunakan pada server dan komputer }\end{array}$ & $\begin{array}{l}\text { Pemasangan UPS, minimal pada } \\
\text { server, akan dianjurkan untuk } \\
\text { pemasangan UPS pada setiap } \\
\text { komputer client yang menginput } \\
\text { data }\end{array}$ & IT Support \\
\hline 3 & $\begin{array}{l}\text { Lantai terbuat dari bahan kayu yang } \\
\text { mudah terbakar }\end{array}$ & $\begin{array}{l}\text { Diadakan peremajaan dan } \\
\text { pemeriksaan terhadap lantai yang } \\
\text { sudah rapuh dan tua, secara } \\
\text { bertahap mengganti lantai } \\
\text { menjadi bahan yang cukup tahan } \\
\text { terhadap guncangan dan api, } \\
\text { sepertikeramik atau semen. }\end{array}$ & $\begin{array}{l}\text { Bagian } \\
\text { Teknisi }\end{array}$ \\
\hline 4 & $\begin{array}{l}\text { Komputer tidak ditutup oleh kain } \\
\text { pengaman yang tahan air }\end{array}$ & $\begin{array}{l}\text { CPU sebaiknya ditutup atau } \\
\text { diselimuti bahan yang kedap air } \\
\text { dan debu setelah jam kerja } \\
\text { selesai. }\end{array}$ & User \\
\hline 5 & $\begin{array}{l}\text { Tidak ada peralatan keamanan untuk } \\
\text { mengamankan peripheral komputer }\end{array}$ & $\begin{array}{l}\text { Dilakukan pemeriksaan terhadap } \\
\text { peripheral komputer yang ada, } \\
\text { dan diberikan alat pengaman agar } \\
\text { tidak mudah disalahgunakan }\end{array}$ & $\begin{array}{l}\text { Kepala } \\
\text { Bagian } \\
\text { masing- } \\
\text { masing }\end{array}$ \\
\hline
\end{tabular}




\begin{tabular}{|c|l|l|c|}
\hline 6 & $\begin{array}{l}\text { Beberapa tempat sampah di dekat } \\
\text { komputer tidak kedap air }\end{array}$ & $\begin{array}{l}\text { Seluruh tempat sampah diganti } \\
\text { dengan yang kedap air dan berada } \\
\text { agak jauh dari barang-barang } \\
\text { elektronik }\end{array}$ & $\begin{array}{c}\text { House } \\
\text { Keeping }\end{array}$ \\
\hline 7 & $\begin{array}{l}\text { Tidak ada prosedur pernulihan dari } \\
\text { bencana alam }\end{array}$ & $\begin{array}{l}\text { Melakukan prosedur bachup } \\
\text { sesering mungkin dan menyimpan } \\
\text { bachup ditempat yang aman }\end{array}$ & IT Support \\
\hline 8 & $\begin{array}{l}\text { Program antivirus yang terpasang } \\
\text { dibeberapa komputer tidak ter-update. }\end{array}$ & $\begin{array}{l}\text { Dilakukan kegiatan update } \\
\text { terhadap program antivirus secara } \\
\text { tutin, minimal satu minggr sekali } \\
\text { dan melakukan aktivitas scanning } \\
\text { terhadap virus secara berkala. }\end{array}$ & IT Support \\
\hline 9 & $\begin{array}{l}\text { Tidak ada prosedur dalam menghadapi } \\
\text { bencana }\end{array}$ & $\begin{array}{l}\text { Dibuat sebuah prosedur untuk } \\
\text { menghadapi bencana secara } \\
\text { tertulis dan mensosialisasikan } \\
\text { prosedur tersebut pada karyawan } \\
\text { serta mengadakan uji coba } \\
\text { pelaksanaan untuk hal tersebut }\end{array}$ & $\begin{array}{c}\text { Support } \\
\text { dareksi }\end{array}$ \\
\hline 10 & Data-data perusahaan tidak dienkripsi & $\begin{array}{l}\text { Dilakukan enkripsi terhadap data } \\
\text { perusahaan dan hanya orang- } \\
\text { orang tertentu saja yang } \\
\text { mengetahui kunci untuk enkripsi } \\
\text { data tersebut. }\end{array}$ & IT Support \\
\hline
\end{tabular}

\section{Pengendalian Aplikasi}

Pengendalian Batasan (Boundary Control)

\begin{tabular}{|c|c|c|c|}
\hline No & Temuan & Rekomendasi & PIC \\
\hline 1 & $\begin{array}{l}\text { Tidak ada pembatasan } \\
\text { password }\end{array}$ & $\begin{array}{l}\text { Adanya pembatasan password } \\
\text { dimana user name yang } \\
\text { bersangkutan akan diblokir jika } \\
\text { terjadi kesalahan peng-irput-an } \\
\text { password dalam jumlah } \\
\text { tertentu. }\end{array}$ & $\begin{array}{l}\text { IT Support dan } \\
\text { pihak ABI Pro }\end{array}$ \\
\hline 2 & $\begin{array}{l}\text { Tidak adanya penggantian } \\
\text { password secara rutin oleh } \\
\text { user }\end{array}$ & $\begin{array}{l}\text { Dibuat sebuah kebijakan } \\
\text { penggantian password untuk } \\
\text { jangka waktu tertentu dan } \\
\text { adanya sosialisasi dengan } \\
\text { karyawan untuk melakukan } \\
\text { penggantian password. }\end{array}$ & $\begin{array}{l}\text { IT Support dan } \\
\text { User }\end{array}$ \\
\hline 3 & $\begin{array}{l}\text { Tidak ada kebiasaan } \\
\text { pengguna untuk logout } \\
\text { dari aplikasi yang } \\
\text { digunakan }\end{array}$ & $\begin{array}{l}\text { Membuat kebijakan untuk } \\
\text { membiasakan karyawan untuk } \\
\text { melakukan logout ketika ingin } \\
\text { meninggalkan pekerjaannya. }\end{array}$ & $\begin{array}{l}\text { IT Supprt dan } \\
\text { User }\end{array}$ \\
\hline 4 & $\begin{array}{l}\text { Aplikasi tidak meminta } \\
\text { user name atau password } \\
\text { jika ditinggal terlalu lama } \\
\text { tanpa di logout }\end{array}$ & $\begin{array}{l}\text { Membuat sebuah program yang } \\
\text { dapat otomatis mengunci } \\
\text { aplikasi dengan password bila } \\
\text { aplikasi tidak digunakan dalam } \\
\text { kurun waktu tertentu. }\end{array}$ & $\begin{array}{l}\text { IT Support dan } \\
\text { ABI Pro }\end{array}$ \\
\hline
\end{tabular}

Pengendalian Input (Input Control)

\begin{tabular}{|c|c|c|c|}
\hline No & Te muan & Rekome ndasi & PIC \\
\hline 1 & $\begin{array}{l}\text { Aplikasi terkadang tidak } \\
\text { memberitahukan } \\
\text { kesalahan }\end{array}$ & $\begin{array}{l}\text { Diadakan pelatihan } \\
\text { untuk karyawan agar } \\
\text { tidak melakukan } \\
\text { kesalahan dalam meng- } \\
\text { input. Menghubungi } \\
\text { pihak penyelia untuk } \\
\text { memperbaiki kesalahan } \\
\text { ini. }\end{array}$ & $\begin{array}{l}\text { IT Support, ABI Pro, dan } \\
\text { User }\end{array}$ \\
\hline
\end{tabular}




\begin{tabular}{|c|c|c|c|}
\hline No & Te muan & Rekome ndasi & $\overline{\text { PIC }}$ \\
\hline 1 & $\begin{array}{l}\text { Pembuatan laporan } \\
\text { tidak dibatasi dari } \\
\text { segi duplikasi dan } \\
\text { periode laporan. }\end{array}$ & $\begin{array}{l}\text { Dibuat sebuah kebijakan } \\
\text { mengenai penerbitan dan } \\
\text { penggandaan laporan. }\end{array}$ & $\begin{array}{l}\text { Kepala Bagian dan } \\
\text { Direksi }\end{array}$ \\
\hline 2 & $\begin{array}{l}\text { Jumlah halaman } \\
\text { laporan tidak } \\
\text { tercetak. }\end{array}$ & $\begin{array}{l}\text { Menghubungi pihak ABI Pro } \\
\text { untuk me mperbaiki aplikasi } \\
\text { sehingga dapat } \\
\text { mencantumkan jumlah } \\
\text { lembar halaman yang tidak } \\
\text { tercetak }\end{array}$ & $\begin{array}{l}\text { IT Support dan } \\
\text { ABI Pro }\end{array}$ \\
\hline 3 & $\begin{array}{l}\text { Untuk printer pita, } \\
\text { tidak terdapat } \\
\text { fasilitas yang } \\
\text { me mberitahukan } \\
\text { jika terjadi } \\
\text { kehabisan pita }\end{array}$ & $\begin{array}{l}\text { Para pengguna printer pita } \\
\text { hanus selalu me mperhatikan } \\
\text { kualitas oufput yang } \\
\text { dihasilkan. Jika kualitas } \\
\text { outout mulai me mburuk } \\
\text { maka pengguna harus } \\
\text { mempersiapkan pita } \\
\text { pengganti yang baru. }\end{array}$ & User \\
\hline 4 & $\begin{array}{l}\text { Bila tidak sampai } \\
\text { ke tujuan, laporan } \\
\text { tidak disimpan di } \\
\text { tempat yang aman }\end{array}$ & $\begin{array}{l}\text { Laporan yang belum sampai } \\
\text { ditujuan harus disimpan } \\
\text { ditempat yang aman. }\end{array}$ & Karyawan \\
\hline 5 & $\begin{array}{l}\text { Tidak ada } \\
\text { konfirm asi bagi } \\
\text { dokumen yang } \\
\text { sudah diterima dan } \\
\text { tidak ada } \\
\text { pencatatan bagi } \\
\text { dokumen yang } \\
\text { belum diterima }\end{array}$ & $\begin{array}{l}\text { Harus dibuat pencatatan } \\
\text { mengenai laporan yang } \\
\text { belum sampai ditujuan dan } \\
\text { dikonfirmasikan kepada } \\
\text { pengirim jika laporan sudah } \\
\text { diterima. }\end{array}$ & Karyawan \\
\hline
\end{tabular}

\begin{tabular}{|c|c|c|c|}
\hline No & Temuan & Rekomendasi & PIC \\
\hline 6 & $\begin{array}{l}\text { Penataan } \\
\text { penyimpanan } \\
\text { oufput yang kurang } \\
\text { rapih dan teratur } \\
\text { sehingga agak sulit } \\
\text { mencarioutput } \\
\text { lama dalam te mpat } \\
\text { penyimpanan } \\
\text { output. }\end{array}$ & $\begin{array}{l}\text { Hatus dilakukan penataan } \\
\text { pada penyimpanan output } \\
\text { dengan lebih teratur dan } \\
\text { rapih }\end{array}$ & $\begin{array}{l}\text { Bagian yang } \\
\text { bersangkutan }\end{array}$ \\
\hline 7 & $\begin{array}{l}\text { Tempat } \\
\text { penyimpanan } \\
\text { oufout kurang } \\
\text { kokoh, tidak tahan } \\
\text { api atau gempa }\end{array}$ & $\begin{array}{l}\text { Disiapkan tempat yang } \\
\text { khusus dan cukup handal } \\
\text { untuk menampung laporan- } \\
\text { laporan yang ada. }\end{array}$ & Bagian teknisi \\
\hline 8 & $\begin{array}{l}\text { Laporan yang } \\
\text { diciptakan tidak } \\
\text { pernah dibuang } \\
\text { atau dimusnahkan }\end{array}$ & $\begin{array}{l}\text { Ditetapkan jangka waktu } \\
\text { batas penyimpanan laporan. }\end{array}$ & $\begin{array}{l}\text { Bagian yang } \\
\text { bersangkutan }\end{array}$ \\
\hline
\end{tabular}




\section{Laporan Audit}

\section{Laporan Evaluasi Sistem Informasi 03 Januari 2007}

Klien : $\mathrm{xx}$

Bagian : Accounting

Kami telah mengadakan evaluasi terhadap sistem General Ledger pada bulan November sampai dengan Desember 2006. Adapun tujuan dilakukannya evaluasi tersebut adalah memastikan pengamanan terhadap asset perusahaan, memastikan integritas data yang ada pada sistem General Ledger, dan meningkatkan efektifitas serta efisiensi sistem General Ledger.

Metode evaluasi yang kami lakukan adalah dengan melakukan penelitian pustakan dan lapangan yang meliputi kegiatan observasi, wawancara, menyebarkan kuesioner, testing program, dan studi dokumentasi. Evaluasi yang kami lakukan menyangkut beberapa hal, yaitu evaluasi terhadap pengendalian manajemen, yang terdiri dari pengendalian manajemen operasi dan pengendalian manajemen keamanan; serta pengendalian aplikasi, yang terdiri dari pengendalian batasan, pengendalian input, dan pengendalian output. Program evaluasi yang kami lakukan meliputi penentuan ruang lingkup evaluasi, pemahaman pengendalian internal, pengumpulan bahan bukti dengan instrumen audit, serta membuat simpulan evaluasi dan rekomendasi atas evaluasi yang kami lakukan.

Berdasarkan pemerikasaan dan pengumpulan bahan bukti yang kami lakukan, kami mendapatkan beberapa temuan dan simpulan, yaitu:

Operation Management Control memiliki beberapa kelemahan, yaitu bagian kasir dan entry data tidak dipisah, tidak ada prosedur pengisian agenda kunjungan dan penggunaan tanda pengenal tamu, ruangan server dapat dimasuki oleh bagian lain selain bagian akuntansi dan bagian keuangan, help desk hanya dapat berjalan di luar aplikasi, dan tidak adanya monitoring terhadap aktivitas pemakaian dan pola perjalanan data. Dengan demikian, kami menyimpulkan bahwa Operation Management Control yang KURANG BAIK.

Security Management Control memiliki beberapa kelemahan, yaitu tidak terdapat smoke detector dan alarm kebakaran, tidak terdapat UPS yang dapat digunakan pada server dan komputer, lantai terbuat dari bahan kayu yang mudah terbakar, komputer tidak ditutup oleh kain pengaman yang tahan air, tidak ada peralatan kemananan untuk mengamankan peripheral komputer, tempat sampah yang tidak kedap air, tidak ada prosedur pemulihan dari bencana alam, Program antivirus yang terpasang dibeberapa komputer tidak ter-update, tidak ada prosedur dalam menghadapi bencana, dan data perusahaan tidak dienkripsi. Dengan demikian, kami menyimpulkan bahwa Security Management Control yang KURANG BAIK.

Boundary Control memiliki beberapa kelemahan, yaitu tidak ada pembatasan password, tidak adanya penggantian password yang dilakukan secara rutin bagi user, tidak ada kebiasaan pengguna untuk logout dari aplikasi yang digunakan, serta Aplikasi tidak meminta user name dan password jika aplikasi tersebut ditinggal terlalu lama tanpa di logout. Dengan demikian, kami menyimpulkan bahwa Boundary control CUKUP BAIK.

Input Control memiliki kelemahan, yaitu pada beberapa bagian aplikasi terkadang tidak memberitahukan kesalahan sehingga kami menyimpulkan bahwa Input Control BAIK.

Output Control memiliki kelemahan, yaitu pembuatan laporan tidak dibatasi dari segi duplikasi dan periode laporan, jumlah halaman laporan tidak tercetak, untuk printer pita tidak terdapat fasilitas yang memberitahukan terjadinya kehabisan pita, bila tidak sampai ketujuan laporan tidak disimpan ditempat yang aman, tidak ada konfirmasi bagi dokumen yang sudah diterima dan tidak ada pencatatan dokumen yang belum diterima, penataan penyimpanan output yang kurang rapi dan teratur, tempat penyimpanan output tidak kokoh, tidak tahan api atau gempa, dan output tidak pernah dibuang atau dihancurkan. Dengan demikian, kami menyimpulkan bahwa Output Control KURANG BAIK.

Berdasarkan temuan dan simpulan tersebut, menurut pendapat kami, Sistem Informasi General Ledger untuk pengendalian manajemen KURANG BAIK sedangkan Sistem General Ledger memiliki pengendalian aplikasi yang CUKUP BAIK.

Oleh karena itu, kami menyimpulkan bahwa Sistem Informasi General Ledger yang berjalan memiliki pengendalian sistem general ledger yang CUKUP BAIK.

Berdasarkan hasil evaluasi yang telah kami sebutkan, ada beberapa hal yang dapat kami rekomendasikan kepada perusahaan, antara lain adanya pemisahan tugas antara bagian kasir dan entry data, adanya sistem yang membatasi akses tamu maupun bagian lain ke dalam ruangan yang sensitif dalam perusahaan, memperbesar memory server agar dapat menampung beban yang lebih besar, memasang smoke detector dan alarm kebakaran dalam gedung, memasang UPS pada server dan komputer penginput, mengadakan peremajaan terhadap bagian 


\section{PENUTUP}

Berdasarkan pemeriksaan dan pengumpulan bahan bukti yang dilakukan, dapat disimpulkan sebagai berikut. Operation Management Control memiliki beberapa kelemahan yang penting, yaitu bagian kasir dan entry data tidak dipisah; Tidak ada prosedur pengisian agenda kunjungan dan penggunaan tanda pengenal tamu; Ruangan server dapat dimasuki oleh bagian lain selain bagian akuntansi dan bagian keuangan; Tidak adanya monitoring atau pengawasan terhadap aktivitas pemakaian dan pola perjalanan data; Help desk hanya berjalan di luar aplikasi. Berdasarkan hal tersebut, Operation Management Control yang ada KURANG BAIK.

Security Management Control juga memiliki cukup banyak kelemahan penting, yaitu tidak terdapat smoke detector dan alarm kebakaran; Tidak terdapat UPS yang dapat digunakan pada server dan komputer; Lantai terbuat dari bahan kayu yang mudah terbakar; Komputer tidak ditutup oleh kain pengaman yang tahan air; Tidak ada peralatan keamanan untuk mengamankan peripheral komputer; Beberapa tempat sampah dekat komputer tidak kedap air; Tidak ada prosedur pemulihan dari bencana alam; Program antivirus yang terpasang dibeberapa komputer tidak ter-update; Tidak ada prosedur menghadapi bencana; Data perusahaan tidak dienkripsi. Dengan demikian, dapat disimpulkan bahwa Security Management Control yang ada KURANG BAIK.

Boundary Control memiliki beberapa kelemahan penting, yaitu tidak ada pembatasan password; Tidak adanya penggantian password yang dilakukan secara rutin bagi user, Tidak ada kebiasaan pengguna untuk logout dari aplikasi yang digunakan; Aplikasi tidak meminta user name dan password jika aplikasi tersebut ditinggal terlalu lama tanpa di logout. Dengan demikian, disimpulkan bahwa Boundary control yang ada CUKUP BAIK.

Input Control hanya memiliki satu kelemahan, yaitu aplikasi terkadang tidak memberitahukan kesalahan yang diperbuat secara jelas. Dapat terlihat bahwa Input Control yang ada sudah BAIK.

Output Control memiliki beberapa kelemahan utama, yaitu pembuatan laporan tidak dibatasi dari segi duplikasi dan periode laporan; Jumlah halaman laporan tidak tercetak; Untuk printer pita, tidak terdapat fasilitas yang bangunan yang sudah menua dan menimbulkan risiko kecelakaan, melakukan pemeriksaan rutin terhadap kondisi komputer dan peripheral-nya, mengefektifkan penggunaan password, adanya tindakan pengamanan terhadap laporan yang belum sampai ditangan penerima, membuat sebuah tempat penyimpanan yang dapat diandalkan, serta membuat sebuah prosedur pemusnahan dokumen yang sudah melebihi batas waktu penggunaan.

Demikian laporan evaluasi yang dapat kami sampaikan sesuai dengan evaluasi yang telah kami lakukan. Semoga laporan ini dapat dipergunakan sebagaimana mestinya. Memberitahukan jika terjadi kehabisan pita; Bila tidak sampai ke tujuan, laporan tidak disimpan di tempat yang aman; Tidak ada konfirmasi bagi dokumen yang sudah diterima dan tidak ada pencatatan bagi dokumen yang belum diterima; Penataan penyimpanan output yang kurang rapi dan teratur sehingga agak sulit mencari output lama dalam tempat penyimpanan output; Tempat penyimpanan dokumen tidak cukup kuat, tahan api, maupun gempa; Output yang tidak terpakai tidak pernah dibuang atau dihancurkan. Dengan demikian, dapat disimpulkan bahwa Output Control yang ada KURANG BAIK

Berdasarkan simpulan tersebut, Sistem Informasi General Ledger memiliki pengendalian manajemen yang KURANG BAIK sedangkan Sistem General Ledger memiliki pengendalian aplikasi yang CUKUP BAIK. Oleh karena itu, disimpulkan bahwa Sistem Informasi General Ledger yang berjalan memiliki pengendalian yang CUKUP BAIK. 


\section{DAFTAR PUSTAKA}

Bodnar, George H. and William S. Hopwood. 2001. Accounting Information Systems. USA: Prentice Hall.

Iwogelius. 2006. "IS Standards, Guidelines and Procedures for Auditing and Control Professionals," Diakses dari http://

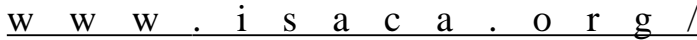
AMTemplate.cfm?Section=Standards2\&Template $=$ / $\mathrm{Content} \mathrm{Manage} \mathrm{ment/}$ ContentDisplay.cfm\&ContentID $=27785$

Jones, Frederick L. dan Dasaratha V. Rama. 2003. Accounting Information Systems. Thomson South Western.

Mulyadi. 2001. Sistem Akuntansi. Salemba Empat. Moskove, Stephen A., Mark G. Simkin, dan Nancy A. Bagranoff. 2001. Core Concepts of Accounting Information Systems. Wiley.

Peltier, Thomas R. 2001. Information Security Risk Analysis. Auerbach.

Romney, Marshall dan Paul John Steinbart. 2006. Accounting Information Systems. Pearson Education, Inc.

Weber, Ron. 1999. Information Systems Control and Audit. Prentice Hall. 